Mr. 17.

Bulletin Forestier Polonais. Revue trimestrielle de l'Union Professionelle des Forestiers de Pologne. Nr. I —. 2. Janvier - Juin 1933.

Mad einer mit beginnendem Şertrauen in die Bufunft bliffenben mirt:

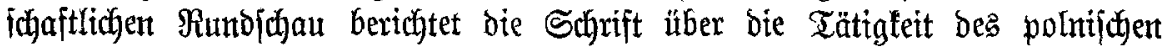
Forjtbereint im Sahre 1932, ferner über Den fibönen Berlauf ber eritmaligent

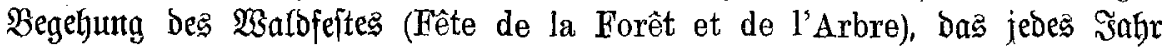
am lebsten Samatag bes Ipril gefeiert werben joll. Bei Diejem Fejt wurben

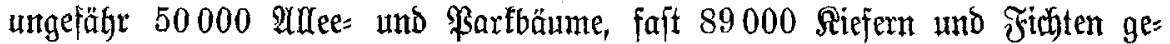

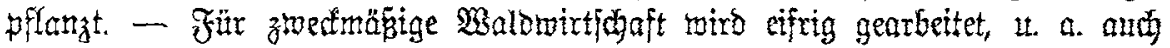
ber Rabio in ben Dienft dex ßropaganoba geftellt.

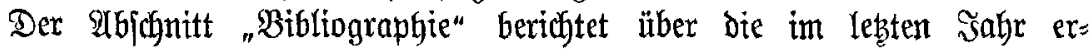

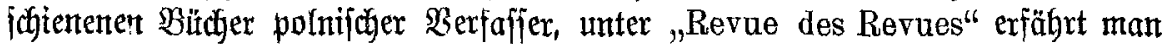

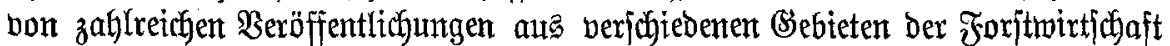
unto Foritwifienjidaft in polnifichen Beitidgriften.

\title{
IV. Kurje 2Tahhrihten.
}

Dorlefungen für Studierende der forftwiffenjh̨aft im Sommerhalbjahr 1934 .

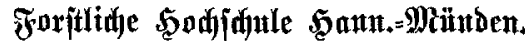

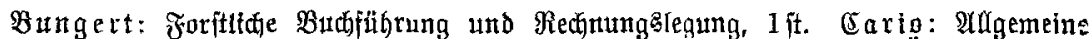
Deteorologite, 2 fi. Eiomann: Forftentomologie, 4 ft.; Foritentomologifde itbungen, 1 ft.;

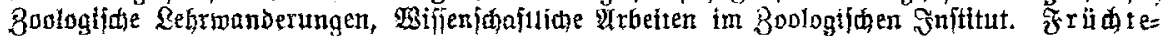

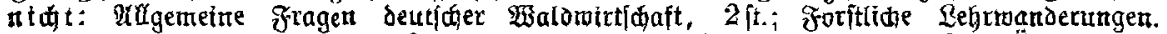

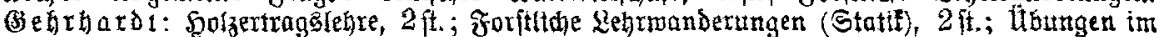

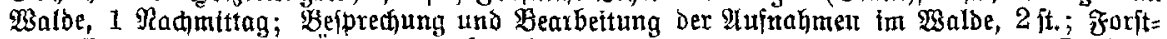
permeffungslegre einfdi. übungen, 1 ft. Fretherr (3eyx von Sdweppenburg: Ornitgo=

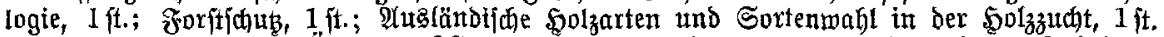

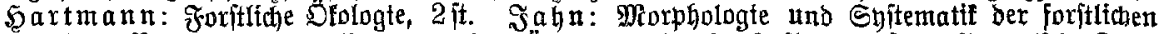

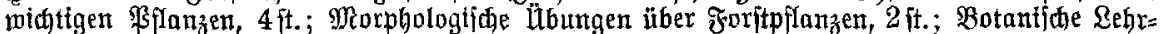

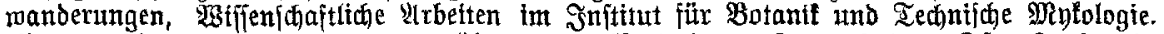

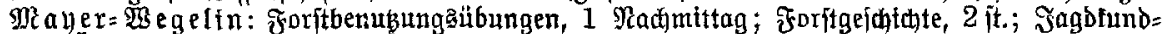

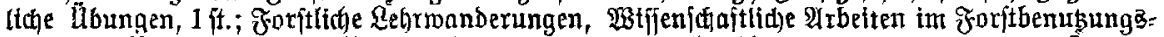

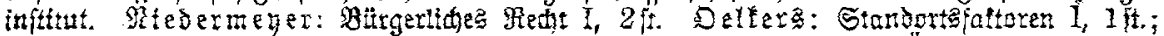

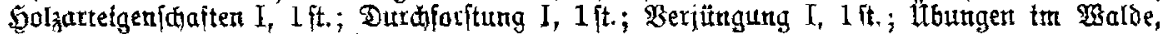

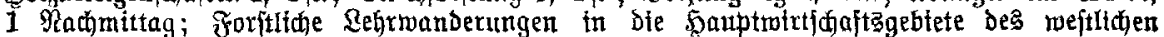

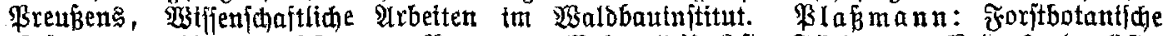

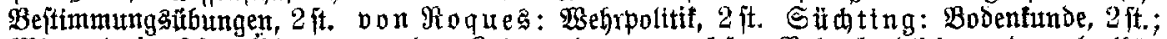

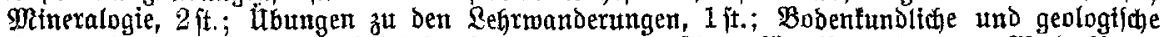

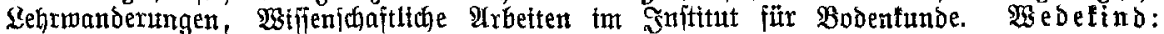

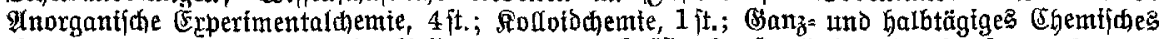

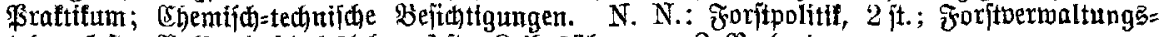

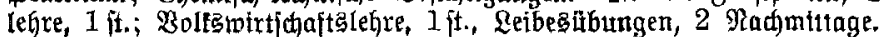

Die Borlefungen beginnen am 2, Mat 1934. Einfdretbung: Montag, ben 23. Wpril

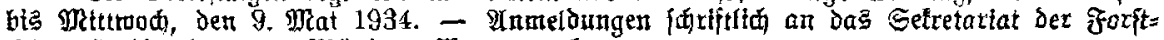

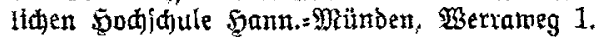

